\title{
Effects of experimental exposure to triethylamine on vision and the eye
}

\author{
Pekka Järvinen, Kerstin Engström, Vesa Riihimäki, Pekka Ruusuvaara, Kirsi Setälä
}

Porin Lääkäritalon Työterveys $\mathrm{Oy}$, Occupational Health and Surgery, Kuninkaanlahdenkatu 14, FIN-28100 Pori, Finland

$P$ Järvinen

Turku Regional Institute of

Occupational Health, Hämeenkatu 10, FIN-20500 Turku, Finland

K Engström

Institute of Occupational Health, Topeliuksenkatu $41 \mathrm{aA}$, FIN-00250 Helsinki, Finland

V Riihimäki

Helsinki University Central Hospital, Department of Ophthalmology, Haartmaninkatu 4, FIN-00290 Helsinki, Finland

P Ruusuvaara

K Setälä

Correspondence to: Dr Pekka Järvinen, Porin Lääkäritalon Työterveys Oy, Occupational Health and Surgery,

Kuninkaanlahdenkatu 14, FIN-28100 Pori, Finland. Fax 00358204803078 .

Accepted 10 July 1998

\begin{abstract}
Objectives-To determine the effect of triethylamine (TEA) on the cornea and to evaluate the cause of blurred vision. To find the lowest observed effect concentration of exposure to TEA.

Methods-Four people were exposed to TEA for 4 hours at concentrations of $\mathbf{4 0 . 6}$, 6.5 , and $3.0 \mathrm{mg} / \mathrm{m}^{3}$. Before and after every exposure, symptoms and ocular microscopy findings were recorded. Binocular visual acuity and contrast sensitivity at $2.5 \%$ contrast were also measured. Also, before and after the $40.6 \mathrm{mg} / \mathrm{m}^{3}$ exposure, corneal thickness was measured and ocular dimensions were recorded by ultrasonography, endothelial cells of the cornea were analysed, and serum and lacrimal specimens were collected for the analysis of TEA.

Results-After exposure to $40.6 \mathrm{mg} / \mathrm{m}^{3}$ TEA there was a marked oedema in the corneal epithelium and subepithelial microcysts. However, corneal thickness increased only minimally because of the epithelial oedema. The lacrimal concentrations of TEA were, on average (range) 41 (18-83) times higher than the serum TEA concentrations. The vision was blurred in all subjects and visual acuity and contrast sensitivity had decreased in three of the four subjects. After exposure to TEA at $6.5 \mathrm{mg} / \mathrm{m}^{3}$ two subjects experienced symptoms, and contrast sensitivity had decreased in three of the four subjects. There were no symptoms or decreases in contrast sensitivity after exposure to a TEA concentration of $\mathbf{3 . 0}$ $\mathbf{m g} / \mathbf{m}^{3}$.

Conclusions-TEA caused a marked oedema and microcysts in corneal epithelium but only minor increases in corneal thickness. The effects may be mediated by the lacrimal fluid owing to its high TEA concentration. Four hour exposure to a TEA concentration of $3.0 \mathrm{mg} / \mathrm{m}^{3}$ seemed to cause no effects, whereas exposure to $6.5 \mathrm{mg} / \mathrm{m}^{3}$ for the same period caused blurred vision and a decrease in contrast sensitivity.

(Occup Environ Med 1999;56:1-5)
\end{abstract}

Keywords: triethylamine; contrast sensitivity; visual symptoms

Amines are widely used as catalysts in the polymerisation reaction between resins and isocyanates. In cold box core making in foundries, this reaction is used as a binder in core sand. In this process triethylamine (TEA) is used in its vapour phase, and it is liberated to the air in an amount that may produce symptoms. The most important symptom caused by amine exposure is blurred, foggy vision. ${ }^{1}$ Most core makers $(78 \%)$ experience blurred vision, and $31 \%$ of them have difficulties in working or driving. ${ }^{2}$ Blurring of vision begins after about 4 hours of exposure and lasts for 2-4 hours after the end of exposure. Deteriorated vision has been detected by contrast sensitivity measurements among core makers. In binocular measurements, contrast sensitivity at $2.5 \%$ contrast has been shown to decrease in $49 \%$ of core makers and $21 \%$ of controls $(\mathrm{p}=0.002) .{ }^{2}$ Exposure to TEA can also provoke mild, work related headaches among people prone to have vascular headaches, although core makers were not found to have the general symptoms of headache more often than referents. ${ }^{3}$

The exact mechanism by which TEA causes blurred vision is not completely understood. Blurred vision, although regarded as a local effect, may be mediated by a systemic mechanism (absorption into the bloodstream after inhalation and secretion by lacrimal production), or it may be caused by a direct diffusion of amine from ambient air, as proposed by previous reports. ${ }^{4}$ Direct application of amine to rabbit eyes was found to cause marked changes in corneal epithelium. ${ }^{5}$ Potts et al described subepithelial vesicles in the cornea of two patients with no ulcerations stained by fluoresceine and no other significant findings. ${ }^{6}$ After experimental exposure to TEA from vapour administered directly on to cat and monkey eyes, they showed severe damage to the cornea or changes close to clinical findings, depending on the concentration of the exposure. ${ }^{6}$ Akesson et al showed a decrease in visual acuity with pronounced corneal oedema confined to the palpebral aperture. ${ }^{4}$ They also measured corneal thickening by an optic Haag-Streit pachymeter after a 4 hour experimental exposure to $48 \mathrm{mg} / \mathrm{m}^{3}$ TEA. However, no increase in corneal thickness was found after the working day in core makers exposed to TEA, when measured by an ultrasonic pachymeter. ${ }^{7}$ No visual symptoms occurred in four volunteers after a single oral dose of TEA or in one volunteer after 1 hour intravenous infusion of TEA. ${ }^{8}$ No evidence of permanent damage caused by repeated exposure to TEA over the course of years could be found in the scientific literature.

There is a wide variation in the reported concentrations of TEA in air that cause blurred vision. Light to moderate symptoms with no changes in visual acuity were found after 8 
Table 1 Study design and measurements conducted on each exposure day

\begin{tabular}{llllll}
\hline $\begin{array}{l}\text { Concentration of } \\
\text { triethylamine } \\
\left(m g / m^{3}\right)\end{array}$ & $\begin{array}{l}\text { Clinical } \\
\text { examination }\end{array}$ & $\begin{array}{l}\text { Visual acuity } \\
\text { and contrast } \\
\text { sensitivity }\end{array}$ & $\begin{array}{l}\text { Ophthalmogical } \\
\text { measurements }\end{array}$ & $\begin{array}{l}\text { Blood } \\
\text { specimens }\end{array}$ & $\begin{array}{l}\text { Lacrimal } \\
\text { specimens }\end{array}$ \\
\hline 40.6 & $\mathrm{x}$ & $\mathrm{x}$ & $\mathrm{x}$ & $\mathrm{x}$ & $\mathrm{x}$ \\
6.5 & $\mathrm{x}$ & $\mathrm{x}$ & $(\mathrm{x})^{\star}$ & $\mathrm{x}$ & \\
3.0 & $\mathrm{x}$ & $\mathrm{x}$ & $\mathrm{x}$ & \\
\hline${ }^{\star}$ Corneal thickness only. & & & &
\end{tabular}

${ }^{\star}$ Corneal thickness only.

Table 2 Lacrimal and serum concentrations of triethylamine ( $\mu \mathrm{mol} / \mathrm{l})$ after $4 \mathrm{~h}$ exposure to $40.6 \mathrm{mg} / \mathrm{m}^{3}$

\begin{tabular}{lccl}
\hline & $\begin{array}{l}\text { Approximate } \\
\text { lacrimal } \\
\text { volume }(\mu l) *\end{array}$ & $\begin{array}{l}\text { Lacrimal } \\
\text { concentration of } \\
\text { triethylamine } \\
(\mu m o l / l)\end{array}$ & $\begin{array}{l}\text { Serum } \\
\text { concentration of } \\
\text { triethylamine } \\
(\mu m o l / l)\end{array}$ \\
\hline 1 & 10 & 53 & 1.78 \\
2 & 2 & 145 & 1.74 \\
3 & 10 & 43 & 2.42 \\
4 & 2 & 115 & 2.83 \\
\hline
\end{tabular}

hours of exposure to TEA in an experimental chamber at a concentration of $18 \mathrm{mg} / \mathrm{m}^{3}$, but no symptoms were found after exposure to 10 $\mathrm{mg} / \mathrm{m}^{3}$ for the same period. ${ }^{4}$ Blurred vision but no changes in visual acuity were found among polyurethane foam workers after being exposed to TEA at an 8 hour time weighted average (TWA) concentration of $10-15 \mathrm{mg} / \mathrm{m} .{ }^{3}{ }^{9}$ Cold box core makers have shown blurry vision when exposed to TWA TEA concentrations of $<0.33-20.3 \mathrm{mg} / \mathrm{m}^{3}{ }^{7}$ Binocular $2.5 \%$ contrast sensitivity was shown to decrease significantly at exposures resulting in urinary TEA concentrations after the shift of $0.3-171 \mathrm{mmol} / \mathrm{mol}$ creatinine. ${ }^{2}$ In the same study, during the contrast sensitivity measurement, the six workers with symptoms had urinary TEA concentrations of $13-171 \mathrm{mmol} / \mathrm{mol}$ creatinine after the shift (data not yet published).

The objectives of this study were to study the ocular effects of high exposure to TEA and to determine the lowest TEA concentration to cause blurred vision or changes in contrast sensitivity.

Table 3 Visual acuity and contrast sensitivity values of the subjects before and after exposure to triethylamine for $4 \mathrm{~h}$ at $40.6,6.5$, and $3.0 \mathrm{mg} / \mathrm{m}^{3}$ (binocular measurements)

\begin{tabular}{|c|c|c|c|}
\hline & \multicolumn{3}{|c|}{ Concentration of triethylamine in air $\left(\mathrm{mg} / \mathrm{m}^{3}\right)$} \\
\hline & 40.6 & 6.5 & 3.0 \\
\hline \multicolumn{4}{|l|}{ Visual acuity: } \\
\hline \multicolumn{4}{|l|}{ Subject 1: } \\
\hline Before exposure & 1.6 & 1.6 & 1.6 \\
\hline After exposure (change as rows) & $1.25(-1)$ & $1.6(0)$ & $1.6(0)$ \\
\hline \multicolumn{4}{|l|}{ Subject 2: } \\
\hline Before exposure & 1.6 & 2.0 & 2.0 \\
\hline After exposure (change as rows) & $1.25(-1)$ & $1.25(-2)$ & $1.6(-1)$ \\
\hline \multicolumn{4}{|l|}{ Subject 3: } \\
\hline Before exposure & 2.0 & 1.6 & 1.6 \\
\hline After exposure (change as rows) & $1.6(-1)$ & $1.6(0)$ & $1.6(0)$ \\
\hline \multicolumn{4}{|l|}{ Subject 4: } \\
\hline Before exposure & 1.25 & 1.25 & 1.25 \\
\hline After exposure (change as rows) & $1.25(0)$ & $1.25(0)$ & $1.25(0)$ \\
\hline \multicolumn{4}{|l|}{ Contrast sensitivity at $2.5 \%$ contrast: } \\
\hline \multicolumn{4}{|l|}{ Subject 1: } \\
\hline Before exposure & 0.63 & 0.8 & 0.63 \\
\hline After exposure (change as rows) & $0.4(-2)$ & $0.63(-1)$ & $0.63(0)$ \\
\hline \multicolumn{4}{|l|}{ Subject 2: } \\
\hline Before exposure & 0.5 & 0.8 & 0.63 \\
\hline After exposure (change as rows) & $0.4(-1)$ & $0.5(-2)$ & $0.63(0)$ \\
\hline \multicolumn{4}{|l|}{ Subject 3: } \\
\hline Before exposure & 0.63 & 0.63 & 0.63 \\
\hline After exposure (change as rows) & $0.32(-3)$ & $0.4(-2)$ & $0.63(0)$ \\
\hline \multicolumn{4}{|l|}{ Subject 4: } \\
\hline Before exposure & 0.5 & 0.5 & 0.5 \\
\hline After exposure (change as rows) & $0.5(0)$ & $0.5(0)$ & $0.5(0)$ \\
\hline
\end{tabular}

\section{Materials and methods}

DESIGN OF THE STUDY

Four sedentary subjects were exposed to TEA for 4 hours on three separate days. Three concentrations were used, the nominal concentrations were 40,10 , and $3 \mathrm{mg} / \mathrm{m}^{3}$, the sequence of the exposures being from the highest to the lowest concentration. On the day of the 40 $\mathrm{mg} / \mathrm{m}^{3}$ exposure, thorough ophthalmological examinations were made to note the effects of TEA on the eye. Serum and lacrimal specimens were also collected for the analysis of TEA. On all the exposure days ocular microscopy was conducted, visual acuity and contrast sensitivity were measured, the symptoms were recorded, and blood samples were collected for analysis of TEA concentrations (table 1).

The study was approved by the research and ethics committees of the Finnish Institute of Occupational Health, and it was carried out in accordance with the Helsinki Declaration. All the participants gave their written informed consent before the study.

\section{SUBJECTS}

During their work day all the subjects were exposed to TEA as core makers. They worked normally on the days preceding the exposures. Three of the subjects were men and one was a woman, their ages ranged from 27 to 53 (mean 41 ) years. They had worked $2-14$ years as core makers (mean 8 years), and their medical history, including ocular history, showed they were all in good general health. The subjects did not do any exercise during the experiments. They were all familiar with contrast sensitivity measurements, as they had taken part in an earlier study on visual effects induced by TEA in industry. ${ }^{2}$

GENERATION OF EXPOSURE

The exposure chamber consisted of a room made of glass and stainless steel with a volume of $10.5 \mathrm{~m}^{3}$. The ventilation of the chamber air was $90 \mathrm{~m}^{3} / \mathrm{h}$. A high concentration TEA-air mixture was generated from a gas wash bottle provided with a thermostat and conducted through warmed stainless steel tubing to the main air stream of the chamber. In the chamber, the TEA concentration was automatically controlled dynamically by the following arrangement. The TEA concentration was continuously monitored by an infra-red gas analyser (Miran 1A, Wilks Foxbro Analytical, South Norwalk, CT, USA). The measurement signal was led to a controller-thyristor unit (Eurotherm 902S / 425A) which controlled the air pump. The desired TEA concentration was set by adjusting the controller unit. An electric fan in the chamber ensured that TEA was homogeneously distributed in the air. The samples for the final analysis of the TEA concentration in the chamber air were collected over the whole 4 hour exposure by pumping air through glass tubes filled with activated charcoal. The TEA was extracted from the charcoal with dimethylformamide and analysed by gas chromatography according to a modified version of the method by Åkesson et al. ${ }^{10}$ 

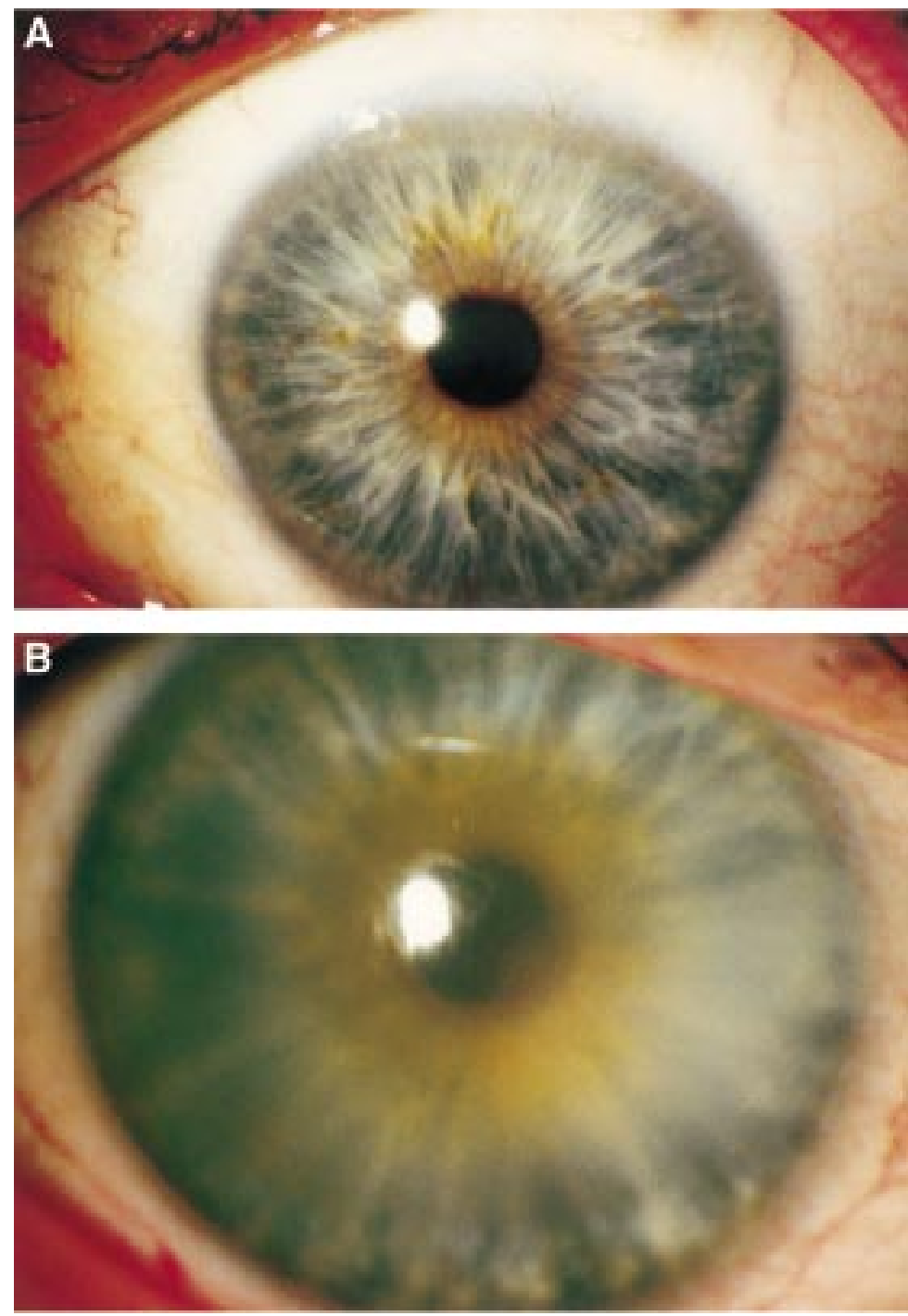

Corneal appearance (A) before exposure to triethylamine for 4 hours, and (B) after exposure of $40.6 \mathrm{mg} / \mathrm{m}^{3}$. The corneal epithelial cells are oedematous, cloudy, and irregular after the exposure, and there are subcorneal vesicles (microcysts).

Table 4 Summary of the symptoms, changes in visual acuity and contrast sensitivity (binocular measurements), and corneal appearance of the subjects after exposure to concentrations of triethylamine of $40.6,6.5$, and $3.0 \mathrm{mg} / \mathrm{m}^{3}$

\begin{tabular}{|c|c|c|c|c|}
\hline $\begin{array}{l}\text { Concentrations of } \\
\text { triethylamine in air }\end{array}$ & Symptoms* & $\begin{array}{l}\text { Full contrast } \\
\text { (change as rows) }\end{array}$ & $\begin{array}{l}2.5 \% \text { Contrast } \\
\text { (change as rows) }\end{array}$ & $\begin{array}{l}\text { Corneal } \\
\text { changes }\end{array}$ \\
\hline \multicolumn{5}{|l|}{$40.6 \mathrm{mg} / \mathrm{m}^{3}:$} \\
\hline Subject 1 & +++ & -1 & -2 & ++ \\
\hline Subject 2 & +++ & -1 & -1 & +++ \\
\hline Subject 3 & +++ & -1 & -3 & +++ \\
\hline Subject 4 & ++ & 0 & 0 & + \\
\hline \multicolumn{5}{|l|}{$6.5 \mathrm{mg} / \mathrm{m}^{3}:$} \\
\hline Subject 1 & $+/-$ & 0 & -1 & $+/-$ \\
\hline Subject 2 & ++ & -2 & -2 & + \\
\hline Subject 3 & - & 0 & -2 & + \\
\hline Subject 4 & _- & 0 & 0 & - \\
\hline \multicolumn{5}{|l|}{$3.0 \mathrm{mg} / \mathrm{m}^{3}:$} \\
\hline Subject 1 & - & 0 & 0 & - \\
\hline Subject 2 & - & -1 & 0 & _- \\
\hline Subject 3 & - & 0 & 0 & - \\
\hline Subject 4 & _- & 0 & 0 & _- \\
\hline
\end{tabular}

$-/+=$ minimal symptoms / corneal changes $+=$ mild symptoms $/$ corneal changes $;++=$ moder ate symptoms / corneal changes; $+++=$ marked symptoms / corneal changes.

BIOLOGICAL SPECIMENS

Blood samples for the analysis of serum TEA were taken by venepuncture before the exposure to determine the residual serum TEA after the core makers' previous shift. Blood samples were taken after the exposure for comparison with the lacrimal TEA concentration. Lacrimal samples were taken by irritating the conjunctiva with a glass capillary tube. After that the specimens were transmitted to polyvinyl chloride tubes for storage before the analyses.

The analyses of the serum and lacrimal specimens were conducted by concentrating the amine in an absorption tube and analysing the TEA by gas chromatography in combination with a thermodesorption technique by a flame ionisation detector. A serum sample (1 $\mathrm{ml}$ ) was added to an impinger vessel containing $1 \mathrm{ml} 0.2 \mathrm{~N} \mathrm{HCl}$ and $0.5 \mathrm{ml}$ of $5 \mathrm{M} \mathrm{KOH}$ with $0.25 \% \mathrm{NH}_{3}$. One drop of antifoam agent was added. Air was drawn through the vessel at a flow rate of $0.1 \mathrm{l} / \mathrm{min}$ for 15 minutes, and the liberated TEA was collected in an absorption tube (Tenax TA). The detection limit for the method was $0.05 \mu \mathrm{mol} / 1$.

\section{VISUAL ACUITY AND CONTRAST SENSITIVITY} TESTING

Visual acuity and contrast sensitivity were tested with optotype test charts at full contrast and $2.5 \%$ contrast (Precision Vision, Villa Park, IL, USA) as already described. ${ }^{2}$ Only binocular measurements were done. The measurements were taken before and immediately after the exposure. The changes between the two measurements were used for the analysis. The change was defined as one row or more on the test chart.

OPHTHAMOLOGICAL EXAMINATIONS

The ophthamological investigations of the eyes were conducted by two clinicians at the Helsinki University Central Hospital near the exposure factory. The clinical investigation with ocular microscopy was carried out before and after every exposure. Ultrasonic measurements of corneal thickness (Humphrey Ultrasonic Pachymeter) were taken before and after the high and medium exposures. Before and after the highest exposure the depth of the anterior chamber and the length of the eye were measured by ultrasonography (Ultrasonic Biometer Humphrey Allergan); the endothelial cells of the central cornea were evaluated with Keeler-Konan contact specular microscopy (Konan SP 5500). The endothelial cells were videotaped and photographed. The cell analysis was done according to the Konan cell analysis system (KC-87 A), which determines the mean cell density, the smallest and largest cell sizes, the mean cell size, the coefficient of variation of the mean cell area, and the frequency of hexagons. The corneas were also photographed for colour prints.

\section{Results}

EXPOSURE AND BIOLOGICAL SAMPLES

The final exposures were 40.6, 6.5, and 3.0 $\mathrm{mg} / \mathrm{m}^{3}$ for the 4 hour exposure periods. The serum TEA values before exposure were low and the lacrimal TEA concentrations before exposure were under the detection limit in all the specimens. After the exposure the eyes of two subjects were dry, and the corresponding lacrimal specimens were low in volume. The 
Table 5 Depth of the anterior chamber, length of the eye, and corneal thickness before and after exposure to triethylamine for $4 \mathrm{~h}$ at a concentration of $40.6 \mathrm{mg} / \mathrm{m}^{3}$

\begin{tabular}{|c|c|c|c|}
\hline Subject & $\begin{array}{l}\text { Depth of the } \\
\text { anterior chamber } \\
\text { (mm right / left eye) }\end{array}$ & $\begin{array}{l}\text { Length of eye } \\
\text { (mm right / left eye) }\end{array}$ & $\begin{array}{l}\text { Corneal thickness } \\
\text { (mm right / left eye) }\end{array}$ \\
\hline \multicolumn{4}{|l|}{ 1: } \\
\hline Before exposure & $3.86 / 3.93$ & $25.10 / 24.82$ & $0.552 / 0.553$ \\
\hline After exposure & $3.86 / 3.53$ & $25.38 / 24.78$ & $0.562 / 0.553$ \\
\hline \multicolumn{4}{|l|}{ 2: } \\
\hline Before exposure & $3.00 / 3.20$ & $24.45 / 24.70$ & $0.517 / 0.534$ \\
\hline After exposure & $2.93 / 3.20$ & $24.44 / 24.63$ & $0.534 / 0.534$ \\
\hline \multicolumn{4}{|l|}{ 3: } \\
\hline Before exposure & $2.86 / 2.80$ & $23.29 / 24.71$ & $0.516 / 0.526$ \\
\hline After exposure & $2.66 / 2.86$ & $23.14 / 22.99$ & $0.534 / 0.534$ \\
\hline \multicolumn{4}{|l|}{ 4: } \\
\hline Before exposure & $3.66 / 3.66$ & $24.77 / 24.90$ & $0.543 / 0.534$ \\
\hline After exposure & $3.40 / 3.40$ & $23.77 / 24.51$ & $0.543 / 0.535$ \\
\hline
\end{tabular}

lacrimal TEA concentrations were, on average (range), 41 (18-83) times higher than the serum TEA concentrations (table 2).

SYMPTOMS, VISUAL ACUITY, CONTRAST

SENSITIVITY, AND CORNEAL APPEARANCE

All the subjects perceived moderate to marked blurring of their vision after 4 hour exposure to a TEA concentration of $40.6 \mathrm{mg} / \mathrm{m}^{3}$, but no one had irritated eyes or respiratory tract. After exposure to $6.5 \mathrm{mg} / \mathrm{m}^{3}$ two of the four subjects perceived minimal to moderate blurring of their vision, but no one had any symptoms after exposure to $3.0 \mathrm{mg} / \mathrm{m}^{3}$.

After exposure to $40.6 \mathrm{mg} / \mathrm{m}^{3}$ visual acuity decreased by one row and contrast sensitivity by $1-3$ rows in three of the four subjects. There were no changes in the vision tests of subject 4 . Exposure to $6.5 \mathrm{mg} / \mathrm{m}^{3}$ caused a decrease in visual acuity in one subject and a decrease in contrast sensitivity in three subjects. After exposure to $3.0 \mathrm{mg} / \mathrm{m}^{3}$ visual acuity decreased in one subject, but the contrast sensitivity remained at the level before exposure in all the subjects (table 3 ).

Ocular microscopy showed oedema in corneal epithelial cells and subepithelial microcysts after exposure to $40.6 \mathrm{mg} / \mathrm{m}^{3}$. The cornea appeared cloudy and the surface irregular (figure). However, the changes seemed to involve only the outermost layer of the cornea and the deep structures were not involved. The changes were most pronounced in the centre of the cornea, where the lacrimal film concentrates. There were marked changes in two subjects and mild to moderate changes in two subjects. After exposure to $6.5 \mathrm{mg} / \mathrm{m}^{3}$ the corneal changes were mild in two subjects and minimal in one. There were no changes in any of the

Table 6 Corneal endothelial cell findings in the subjects before and after exposure to triethylamine for $4 \mathrm{~h}$ at a concentration of $40.6 \mathrm{mg} / \mathrm{m}^{3}$

\begin{tabular}{|c|c|c|c|}
\hline Subject $($ age, $y)$ & $\begin{array}{l}\text { Cell density } \\
\text { (cells/mm }{ }^{2} \text { right / left eye) }\end{array}$ & $\begin{array}{l}C V \\
\text { (right / left eye) }\end{array}$ & $\begin{array}{l}\text { Hexagonal cells } \\
(\% \text { right / left eye) }\end{array}$ \\
\hline \multicolumn{4}{|l|}{$1(33)$} \\
\hline Before exposure & $3533 / 3344$ & $0.23 / 0.21$ & $88 / 90$ \\
\hline After exposure & $3490 / 3402$ & $0.22 / 0.21$ & $80 / 88$ \\
\hline \multicolumn{4}{|l|}{$2(53)$} \\
\hline Before exposure & 2577 / 2631 & $0.22 / 0.24$ & $74 / 62$ \\
\hline After exposure & $2502 / 2700$ & $0.20 / 0.22$ & $76 / 72$ \\
\hline \multicolumn{4}{|l|}{$3(50)$} \\
\hline Before exposure & $2695 / 2583$ & $0.21 / 0.25$ & $50 / 68$ \\
\hline After exposure & $2590 / 2640$ & $0.24 / 0.21$ & $56 / 68$ \\
\hline \multicolumn{4}{|l|}{$4(27)$} \\
\hline Before exposure & 3058 / 3012 & $0.18 / 0.23$ & $77 / 76$ \\
\hline After exposure & $3100 / 3058$ & $0.20 / 0.19$ & $75 / 77$ \\
\hline
\end{tabular}

$\mathrm{CV}=$ coefficient of variation for the mean cell area. subjects after exposure to $3.0 \mathrm{mg} / \mathrm{m}^{3}$. A summary of the symptoms, the changes in visual acuity and contrast sensitivity, and corneal appearance is presented in table 4 .

\section{OPHTHAMOLOGICAL MEASUREMENTS}

There was minimal corneal thickening (2\%-4\% increase) after exposure to 40.6 $\mathrm{mg} / \mathrm{m}^{3}$ in at least one eye of the subjects except subject 4 , who had no changes (table 5). After exposure to $6.5 \mathrm{mg} / \mathrm{m}^{3}$ there were no changes in corneal thickness. There were no clinically relevant changes in the depth of the anterior chamber of the eye or in the length of the eye (table 5). Endothelial cell microscopy showed no clinically relevant changes in cell density, the coefficient of variation of the mean cell area, or the proportion of hexagonal cells (table 6). The endothelial cell variables were within normal limits for the ages of the subjects.

\section{Discussion}

It is obvious that the critical effect of exposure to TEA is blurred vision. Former studies in which TEA was directly applied to the eyes cannot conclusively identify the mechanism of blurred vision because they have not considered the systemic absorption of the amine. The restriction of the reported changes to the palpebral aperture are also difficult to understand because of the continuous blinking movements of the palpebrae.

This study attempted to verify corneal changes after exposure to TEA by methods currently available in clinical ophthalmology and to search for the lowest observed effect concentration of exposure to TEA with the use of contrast sensitivity measurements. It is typical for exposure to TEA that blurred vision occurs without irritative symptoms of the eye. Typical corneal changes have been described earlier, ${ }^{6}$ but there have been different reports on corneal thickness after exposure to TEA. ${ }^{4} 7$ Triethylamine is a highly alkaline substance with a $\mathrm{pH}$ of 11.9 (0.1 M solution), and high TEA concentrations cause corrosion of the corneal epithelium. ${ }^{56}$ Both the strong alkalinity and the bipolarity of TEA molecules may play a part in the aetiology of changes in the cornea. There have been inconsistent reports on TEA concentrations causing impairment in visual acuity after exposure chamber experiments ${ }^{4}$ and symptoms under actual working conditions. ${ }^{7}$ New, more accurate methods are now available with which to indentify the changes. Contrast sensitivity measurement has proved to be as sensitive as the observation of symptoms in the documentation of visual effects induced by TEA. ${ }^{2}$

The corneal changes found confirm the present assumption of the cause of blurred vision. Oedema of the corneal epithelium and subepithelial microcysts caused light scattering, and therefore, also a blurring of vision. Apparently the small thickening of the cornea was solely caused by the oedema of the corneal epithelium. The TEA influenced only the corneal layer, which exfoliates daily from the epithelium. This finding was further confirmed by the results of the endothelial cell micros- 
copy, which showed no changes in the endothelial cells and indicated normal levels for the ages of the subjects.

Contact lenses may cause changes in the corneal epithelium and symptoms of blurred vision-for example, after too long a period of continuous use. They also act as a reservoir for TEA prolonging the exposure. Therefore it is extremely important not to wear contact lenses during exposure to TEA.

The changes were strongest in the centre of the cornea, where the lacrimal film concentrates, and TEA concentrations in lacrimal fluid were remarkably higher than the serum concentrations. Thus, the TEA induced corneal changes might be caused by concentrating TEA by lacrimal secretion. However, there were wide variations in the ratio of lacrimal:serum TEA concentrations, and the lacrimal TEA concentrations seemed to be inversely related to the volume of lacrimal samples. The eyes of the subjects were dry after exposure to TEA probably because of the anticholinergic effect of TEA. This caused difficulties in collecting the lacrimal samples. There is no agreed method of a correction for sample dilution of lacrimal specimens as there is for urine samples. No previous reports on the measurements of aliphatic amines from lacrimal fluid could be found in the literature, and the results of the lacrimal specimens in this study should be considered as preliminary information in the area.

The possibility of systemic absorption of TEA as a contributing factor to corneal changes is also supported by the latency of the occurrence of symptoms after the beginning of the working day. Also, in a former study three of the four subjects exposed for 8 hours to a TEA concentration of $20 \mathrm{mg} / \mathrm{m}^{3}$ experienced blurred vision, but after ingestion of ethanol, which increases TEA excretion, no one had visual symptoms after the same exposure. ${ }^{11}$

Contrast sensitivity measurement proved to be of value in measuring the visual symptoms caused by toxic effects on the cornea. According to our previous study, binocular measurements at $2.5 \%$ contrast give the most accurate results. ${ }^{2}$ Contrast sensitivity examinations seem to be as sensitive as the finding of symptoms in evaluation of visual phenomena induced by TEA. We found a dose-response relation between exposure to TEA and our results of the visual acuity and contrast sensitivity measurements. At an exposure of $40.6 \mathrm{mg} / \mathrm{m}^{3}$ both visual acuity and contrast sensitivity had decreased in three of the four subjects, whereas at $6.5 \mathrm{mg} / \mathrm{m}^{3}$ visual acuity had decreased only in one subject and contrast sensitivity in three. There were no decreases in contrast sensitivity at an exposure of $3.0 \mathrm{mg} / \mathrm{m}^{3}$, but visual acuity decreased in one subject. However, the decrease in visual acuity of subject 2 at $3.0 \mathrm{mg} / \mathrm{m}^{3}$ is considered to be due to variations in measurements. In this study $6.5 \mathrm{mg} / \mathrm{m}^{3}$ was the lowest concentration of TEA to induce visual changes at rest, and $3.0 \mathrm{mg} / \mathrm{m}^{3}$ was the corresponding no observed effect concentration.
Nevertheless, some individual variation occurs in the manifestation of symptoms and decreases in visual measurements. In this study one subject showed no decrease in contrast sensitivity and another subject was more prone to have visual changes than the others.

Because the visual symptoms usually appear within 4 hours after the beginning of the working day, the results of the 4 hour experiments can probably be applied to 8 hour exposures in industry.

\section{Conclusions}

Four hours of experimental exposure to a TEA concentration of $40.6 \mathrm{mg} / \mathrm{m}^{3}$ at rest caused marked oedema and irregularities in corneal epithelium and subepithelial microcysts. These changes probably cause light to scatter and the vision to blur. The increase in corneal thickness was minimal and caused only by the oedema in the outermost corneal layer. No changes were found in the endothelial cells.

The TEA concentrations were 41 (range 18-83) times higher in the lacrimal fluid than in serum samples. The changes in corneal epithelium were most prominent in the centre of the cornea, where the lacrimal film concentrates. These findings support the assumption that the effects on the eye are mediated by the lacrimal fluid, and therefore systemic TEA uptake may be of importance.

Contrast sensitivity measurement proved to be the most valuable means of measuring symptoms of the eyes induced by TEA. Although some individual variations were found for the symptoms and measurements, contrast sensitivity showed that exposure to 6.5 $\mathrm{mg} / \mathrm{m}^{3}$ TEA caused measurable effects, but 3.0 $\mathrm{mg} / \mathrm{m}^{3}$ did not.

This study was supported by the Finnish Work Environment Fund.

1 Albrecht W, Stephenson R. Health hazards of tertiary amine catalysts. Scand F Work Environ Health 1988;14:209-19.

2 Järvinen P, Hyvärinen L. Contrast sensitivity measurement in evaluations of visual symptoms caused by exposure to triethylamine. Occup Environ Med 1997;54:483-6.

3 Järvinen P. Headache and blood pressure among triethylamine-exposed foundry workers. Occup Med 1998; 48:113-17.

4 Åkesson B, Floren I, Skerfving S. Visual disturbances after experimental human exposure to triethylamine. $B r \mathcal{F}$ Ind Med 1985;42:848-50.

5 Mellerio J, Weale RA. Hazy vision in amine plant operatives. Mellerio J, Weale RA. Hazy vis
Br f Ind Med 1966;23:153-4.

6 Potts AM, Rouse EF, Eiferman RA, et al. An unusual type of keratopathy observed in polyurethane workers and its reproduction in experimental animals. Am F Ind Med 1986; 9:203-13.

7 Reilly M, Rosenman K, Abrams J, et al. Ocular effects of exposure to triethylamine in the sand core cold box of a foundry. Occup Environ Med 1995;52:337-43.

8 Åkesson B, Vinge E, Skerfving S. Metabolism of triethylamine and triethylamine-N-oxide in man. Toxicol Appl Pharmacol 1989;100:529-38.

9 Åkesson B, Bengtsson M, Floren I. Visual disturbances after industrial triethylamine exposure. Int Arch Occup Environ industrial triethylamine

10 Åkesson B, Skerfving S, Mattiasson L. Experimental study on the metabolism of triethylamine in man. Br f Ind Med 1988;45:262-8

11 Åkesson B, Skerfving S. Effects of ethanol ingestion and urinary acidity on the metabolism of triethylamine in man. Int Arch Occup Environ Health 1990;62:89-93. 